StanisŁaW SALA

Akademia Świętokrzyska, Kielce

\title{
Polskie firmy na tle zagranicznych korporacji w dobie globalizacji
}

Początki korporacji transnarodowych (KTN) sięgają epoki wielkich odkryć geograficznych. Wówczas pierwsze korporacje zajmowały się wymianą handlową między ówczesnymi metropoliami a terytoriami zamorskimi. W epoce wiktoriańskiej powstał wolny rynek, którego zasady przyczyniły się do ukształtowania nowoczesnego sposobu funkcjonowania korporacji. Jednak dopiero wskutek rozwoju telekomunikacji i nowoczesnych środków transportu, od początku lat 70. XX wieku, obserwujemy gwałtowne przyspieszenie rozwoju KTN.

W wyniku wzrostu znaczenia procesów związanych z umiędzynarodowieniem przedsiębiorstw i produkcji, KTN dysponują bardzo dużym kapitałem produkcyjnym i technologicznym generującym olbrzymie zyski, jak również ogromną siłą ekonomiczną, na którą składają się przede wszystkim duża wartość sprzedaży oraz nowoczesne technologie i wykwalifikowana siła robocza. O ich potędze świadczy fakt, że niejednokrotnie dochody KTN przekraczają wartość PKB średnio rozwiniętych krajów. Obecnie około 50 korporacji transnarodowych zaliczanych jest do 100 największych gospodarek funkcjonujących na świecie, a 13 znajduje się w pierwszej pięćdziesiątce.

Korporacje transnarodowe (KTN) powszechnie uznaje się za siłę napędową oraz głównych beneficjentów globalizacji. Rola i znaczenie jakie korporacje odgrywają na arenie międzynarodowej jest przyczyną zainteresowania specjalistów licznych dziedzin nauki [Domański 1996, 2001, 2002; Jarczewska-Romaniuk 2004; Karaszewski (red.) 2003; KisielŁowczyc 2000; Romanowska, Trocki, Wawrzyniak, 2000; Sala 2003; Zorska 2000, 2002]. Szacuje się, że obecnie działa około 63 tys. korporacji transnarodowych dysponujących ponad 820 tysiącami zagranicznych filii, łącznie zatrudniających ponad 6 mln pracowników. Wartość sprzedaży wytworzonych przez wszystkie korporacje wyrobów i usług w 2000 roku wyniosła 15680 USD, co daje kwotę przewyższającą ponad 2,2 razy wartość światowego eksportu. Natomiast łączna wartość produktu brutto korporacji transnarodowych stanowi około 25\% światowego PKB [UNCTAD 2001]. KTN aspirują do miana najbardziej aktywnych podmiotów w gospodarce globalnej [Thurow 1996, 1997, 1999; Cziomer, Zyblikiewicz 2000; Skodlarski, Matera 2004].

Tworzenie i rozwijanie korporacji przez poszczególne kraje wydaje się być jednym z najszybszych sposobów akumulacji kapitału. Polska, pragnąc jak najszybciej dołączyć do grupy krajów najlepiej rozwiniętych, powinna również stworzyć sprzyjające warunki dla rozwoju rodzimych korporacji. 
Celem artykułu jest przedstawienie polskich korporacji na tle największych korporacji na świecie.

\section{ZARYS ROZWOJU POLSKICH KORPORACJI}

Procesy globalizacji zaowocowały wejściem polskiej gospodarki na rynek globalny poprzez coraz lepiej prosperujące firmy. Za początek tworzenia się nowej generacji przedsiębiorstw w Polsce należy uznać datę 13 lipca 1990 roku, kiedy to została uchwalona ustawa, na mocy której rozpoczęto procesy prywatyzacyjne trwające po dzień dzisiejszy. Za główny cel procesów prywatyzacyjnych należy uznać dostosowanie polskiej gospodarki do wymogów współczesnego świata, a w szczególności do sprostania presji konkurencyjnej ze strony przedsiębiorstw międzynarodowych poprzez:

- rozbudowę nowoczesnych gałęzi przemysłu (głównie przemysły zaawansowanych technologii),

- restrukturyzację przestarzałych gałęzi przemysłu (górnictwa, hutnictwa, przemysłu koksowniczego, energetyki),

- rozwój infrastruktury technicznej.

Efektem restrukturyzacji polskiej gospodarki jest dynamiczny rozwój firm, głównie prywatnych. W Polsce na koniec 2002 r. liczba przedsiębiorstw wynosiła 1,7 mln firm, z czego 99\% stanowiły przedsiębiorstwa małe zatrudniające do 49 osób, 0,8\% - średnie przedsiębiorstwa zatrudniające od 50 do 249 osób, a duże przedsiębiorstwa - ok. 0,2\%, natomiast ich udział w PKB przekraczał 50\%, co dobitnie pokazuje ich rangę w gospodarce krajowej.

Rozmieszczenie największych polskich przedsiębiorstw nie jest równomierne, zdecydowanie na pierwszym miejscu plasuje się województwo mazowieckie z zarejestrowanymi 614 firmami przekraczającymi $50 \mathrm{mln}$ złotych przychodu, drugie miejsce zajmuje województwo śląskie z 275 największymi firmami. Na tle Polski stosunkowo nieźle prezentują się województwa: małopolskie, pomorskie, wielkopolskie oraz dolnośląskie, jednak różnica między nimi a województwem mazowieckim jest bardzo duża.

Rozwój polskich firm jest niezaprzeczalny, o czym może świadczyć duża dynamika przychodów osiagająca nawet do $600 \% \mathrm{w}$ ciagu roku (tab. 1). Jednak w pierwszej dziesiątce najszybciej rozwijających się polskich przedsiębiorstw dynamika przychodów kształtuje się na poziomie 118-240\% w latach 2001-2002. W 2003 roku dynamika przychodów małych firm średnio wyniosła $111,3 \%$, średnich - $114,8 \%$, a dużych $-110,8 \% \mathrm{w}$ stosunku do roku 2002. Jeszcze lepiej przedstawia się sytuacja, gdy porównamy ze sobą rok 2003 i 2000. W tym okresie dynamika przychodów dziesięciu najszybciej rozwijających się firm w Polsce kształtowała się między 1080,0\% a 2779,6\% (tab. 1). Na uwagę zasługuje duża rotacja firm zaliczanych do 100 najcenniejszych firm prywatnych w Polsce. Porównując ranking z 2003 z rankingiem z 2002 roku należy zwrócić uwagę na istotne zmiany. Z rankingu z 2003 r. jedynie 54 były odnotowane w 2002 roku. Świadczy to o bardzo dużej rotacji firm, spowodowanej ostrą konkurencją na rynku, a także brakiem stabilizacji firm. Natomiast mała wartość polskich przedsiębiorstw uniemożliwia skuteczną walkę o utrzymanie zeszłorocznej pozycji. Wśród 54 firm obecnych w rankingu w latach 2002 i 2003, 38 zanotowało spadek wartości, a jedynie 16 firm odnotowało jej wzrost. Największy spadek wartości zanotowały: 
JTT Computer S.A. (-72,8\%), Big Star Limited (-71,6\%), Kolporter Service S.A. (-68,2\%), Techmex S.A. (-67,9\%), Fabryka Maszyn Glinik S.A. (-60,4\%) oraz Technokabel (-59,5\%). Natomiast najwyższe wartości wzrostu wartości zanotowały: Zakłady Tłuszczowe Bielmar (143,6\%), Zakłady Mięsne Mazury (108,4), Sonda S.A. (97,4\%), Grupa Atlas (80,6\%), Mikrotech SA (79,6\%), oraz Gdańska Stocznia Remontowa (78,2\%).

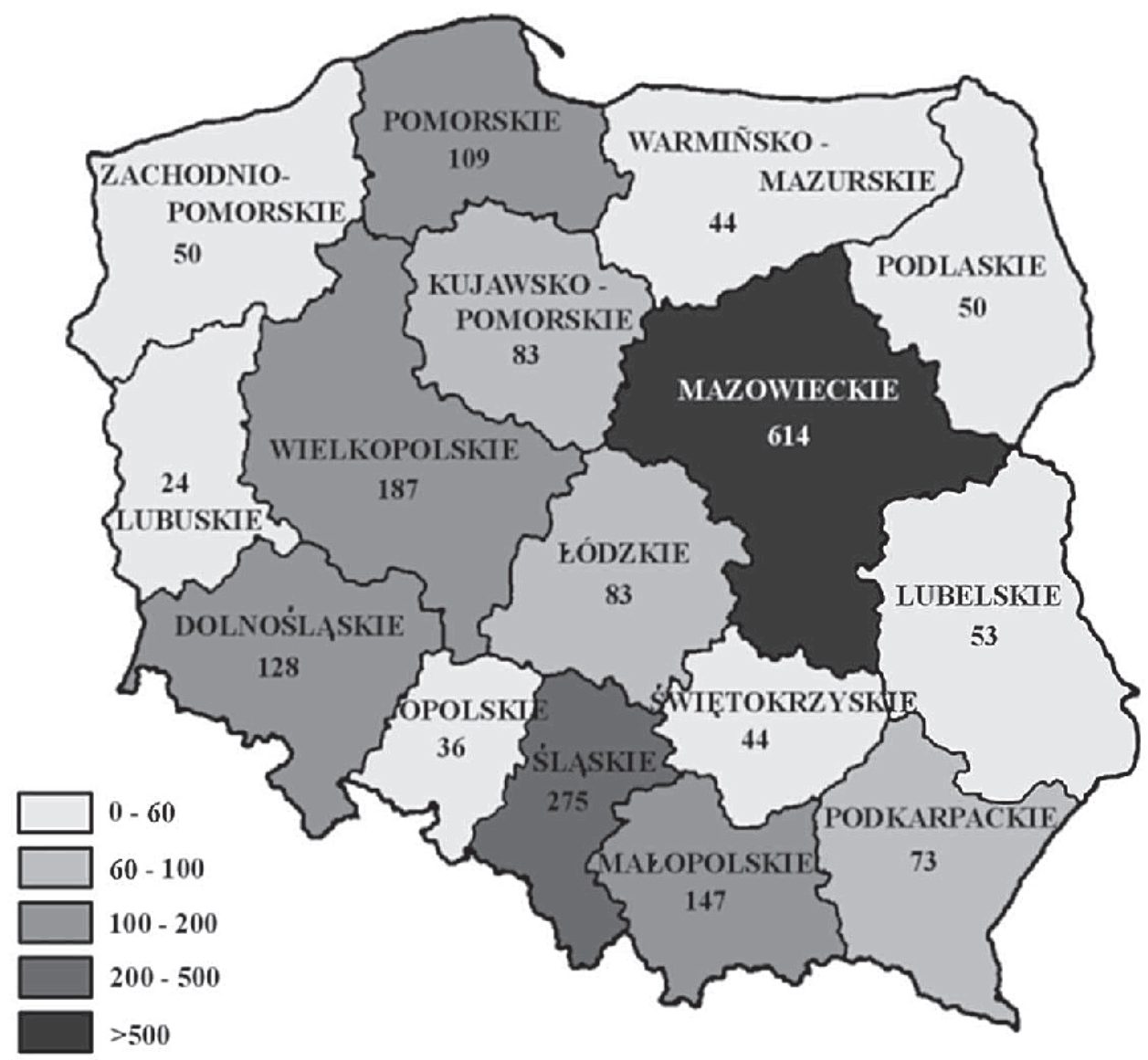

Ryc. 1. Liczba największych firm przekraczających 50 mln złotych przychodu według województw w 2003 r.

Źródło: opracowanie własne na podstawie: Lista 2000, „Rzeczpospolita” z dn. 12.09.2004

Wejście Polski do Unii Europejskiej stworzyło niepowtarzalną okazję dla ekspansji polskich firm. Z jednej strony polskie przedsiębiorstwa narażone są na bardzo ostrą konkurencję firm zachodnich, natomiast $\mathrm{z}$ drugiej - akcesja otworzyła - nowe rynki zbytu dla krajo- 
wych towarów. Sytuację komplikują wysokie koszty pracy, niespójne i szybko zmieniające się przepisy prawa podatkowego i gospodarczego. System podatkowy w Polsce jest bardzo skomplikowany co prowokuje do licznych nadużyć. Ponadto w Polsce brak jest atrakcyjnych pod względem inwestycyjnym uzbrojonych terenów, posiadających uregulowane kwestie własnościowe. W przypadku kiedy takie tereny wystawione są na sprzedaż, polscy inwestorzy dysponujący znacznie mniejszym kapitałem od inwestorów zagranicznych najczęściej z nimi przegrywają rywalizację. Poważnym utrudnieniem dla rozwoju polskich firm jest również brak aktywnej polityki gospodarczej rządu w zakresie wspierania biznesu. Rola rządu bardzo często kończy się na dobrych deklaracjach, za którymi niestety nie idą odpowiednie uregulowania prawne. Minusem utrudniającym rozwój firm w Polsce jest niedostateczny rozwój infrastruktury transportowej. Na szczególną uwagę zasługuje brak autostrad, co z jednej strony utrudnia dystrybucję towarów, a z drugiej podraża koszty transportu. Kolejnym mankamentem jest korupcja wśród urzędników państwowych, nepotyzm, a także biurokracja w urzędach. W przypadku korupcji firmy pozbawione są równych szans na rynku, natomiast biurokracja zmusza do poświęcania zbyt dużo czasu sprawom administracyjnym, rachunkowym czy podatkowym, kosztem kwestii związanych z marketingiem, produkcją czy dystrybucją towarów i usług. Wejście Polski do Unii Europejskiej wymusza wprowadzanie u nas unijnych standardów prawnych i finansowych, co z pewnością przyczyni się do polepszenia warunków prowadzenia biznesu w naszym kraju.

Tabela 1. Najszybciej rozwijające się przedsiębiorstwa w Polsce według dynamiki przychodów

\begin{tabular}{|r|l|l|c|}
\hline Lp. & \multicolumn{1}{|c|}{ Nazwa przedsiębiorstwa } & \multicolumn{1}{|c|}{ Miejscowość } & $\begin{array}{c}\text { Dynamika przychodów } \\
2003 / 2000(\mathrm{w} \%)\end{array}$ \\
\hline 1. & Fiat-GM & Bielsko-Biała & 2779,6 \\
\hline 2. & Sydo & Wrocław & 1905,2 \\
\hline 3. & Celt Glas SA & Tychy & 1893,9 \\
\hline 4. & Żaka Polska & Poznań & 1636,1 \\
\hline 5. & Stocznia Szczecińska Nowa & Szczecin & 1597,2 \\
\hline 6. & Zakład Maszyn Górniczych Glinik & Gorlice & 1507,3 \\
\hline 7. & Morpol & Szczecin & 1459,6 \\
\hline 8. & Polska Energia & Katowice & 1204,8 \\
\hline 9. & Opoczno SA & Opoczno & 1106,0 \\
\hline 10. & Mokate & Żory & 1080,0 \\
\hline 11. & Skanska Polska SA GK & Warszawa & 1064,7 \\
\hline 12. & Polsped-Gerlach & Słubice & 1035,3 \\
\hline 13. & Fideltronik Imel & Sucha Beskidzka & 950,4 \\
\hline 14. & Przeds. Handlu Tekstyliami & Białystok & 909,9 \\
\hline 15. & Strabag & Warszawa & 871,3 \\
\hline 16. & Altana Pharma & Warszawa & 868,4 \\
\hline 17. & Tetra Pak & Warszaw & 819,2 \\
\hline 18. & Browar Belgia & Kielce & 778,3 \\
\hline 19. & Kingspan & Lipsko & 740,5 \\
\hline 20. & Boryszew S.A. GK & Sochaczew & 731,9 \\
\hline & & & \\
\hline
\end{tabular}




\section{POLSKIE KORPORACJE NA TLE NAJWIĘKSZYCH KORPORACJI ŚWIATA}

Stosunkowo krótki okres transformacji nie pozwolił na wykształcenie się licznych firm, odgrywających istotną rolę na arenie międzynarodowej. Do 2003 roku „BusinessWeek” prowadził dwie listy przedstawiające największe na świecie spółki pod względem kapitalizacji rynkowej. Pierwsza lista obejmowała 1000 największych firm wywodzących się z krajów wysoko rozwiniętych, natomiast druga przedstawiała 200 najcenniejszych firm rynków wschodzących obejmujących kraje rozwijające się, w tym kraje Europy Środkowej i Wschodniej. Na liście 200 najcenniejszych firm rynków wschodzących znalazły się cztery polskie przedsiębiorstwa (tab. 2).

Analizując dane zamieszczone w tabeli 2, zwraca uwagę mała wartość rynkowa polskich korporacji w porównaniu z najcenniejszą korporacją rynków wschodzących, oraz duża rentowność Banku Pekao. Średnia dynamika przychodów dużych polskich firm $(110,8 \%)$ jednoznacznie wskazuje na ich rozwój. Jednak, analizując rozwój polskich korporacji na tle 200 najcenniejszych firm rynków wschodzących obraz nie przedstawia się już tak optymistycznie. Telekomunikacja Polska w 2003 roku nie utrzymała lokaty z 2002 roku i spadła z 60 na 63 miejsce. Podobnie sytuacja przedstawia się z pozostałymi polskimi korporacjami: Bank Pekao spadł z 65 na 75 pozycję, Polski Koncern Naftowy ORLEN - z 165 miejsca na 180 miejsce oraz Bank Przemysłowo-Handlowy PBK z 159 na 183 miejsce.

W 2003 roku korporacje pochodzące z tzw. rynków wschodzących nie były uwzględnione na liście Global 1000. Porównując dwie największe polskie korporacje z listą Global 1000, zauważamy, że Bank Pekao zajmuje 877 miejsce, natomiast Telekomunikacja Polska S.A. - 737 pozycję. W 2004 roku „BusinessWeek” na podstawie badań Morgan Stanley Capital International opublikował już tylko jedną listę najwartościowszych korporacji świata, obejmującą zarówno kraje rozwinięte, jak i rozwijające się. Na liście Global 1000 w 2004 roku znalazły się tylko dwie polskie korporacje. Na miejscu 985 sklasyfikowany został Bank Pekao i na 987 pozycji znalazła się Telekomunikacja Polska S.A. Na uwagę zasługuje fakt, że obydwie polskie korporacje w 2004 roku nie utrzymały pozycji z 2003 roku. Bank PEKAO spadł aż o 108 miejsc, natomiast Telekomunikacja Polska S.A. aż o 250 miejsc (tab. 3). Natomiast Polski Koncern Naftowy ORLEN oraz Bank PrzemysłowoHandlowy PBK ze względu na wartość rynkową nie zmieściły się w 1000 najwartościowszych korporacji świata.

Tabela 2. Polskie korporacje na tle 200 najcenniejszych firm rynków wschodzących

\begin{tabular}{|c|c|c|c|c|c|c|}
\hline \multicolumn{2}{|c|}{ Pozycja } & \multirow{2}{*}{ Nazwa korporacji } & \multirow{2}{*}{$\begin{array}{l}\text { Wartość } \\
\text { rynkowa }\end{array}$} & \multirow{2}{*}{$\begin{array}{l}\text { Rentowność } \\
\quad(\mathrm{w} \%)\end{array}$} & \multirow{2}{*}{$\begin{array}{c}\text { Sprzedaż } \\
\text { (w mln USD) }\end{array}$} & \multirow{2}{*}{$\begin{array}{c}\text { Zyski } \\
\text { (w mln } \\
\text { USD) }\end{array}$} \\
\hline 2003 & 2002 & & & & & \\
\hline 1. & 1. & China Mobil (Hong Kong) & 440899 & 1,8 & 15533 & 3956 \\
\hline 63. & 60. & Telekomunikacja Polska SA & 5071 & 0,7 & 5045 & 247 \\
\hline 75. & 65. & Bank Pekao & 4115 & 4,5 & - & 207 \\
\hline 180. & 165. & Polski Koncern Naftowy & 2065 & 0,7 & 4552 & 113 \\
\hline 183. & 159. & $\begin{array}{l}\text { Bank Przemysłowo-Handlowy } \\
\text { PBK }\end{array}$ & 2034 & 1,4 & - & 36 \\
\hline 200. & 117. & Grupo Bimbo (Meksyk) & 1875 & 1,3 & 4002 & 94 \\
\hline
\end{tabular}

Źródło: opracowanie własne na podstawie: Morgan Stanley Capital International za: „BusinessWeek” z 08.2003 


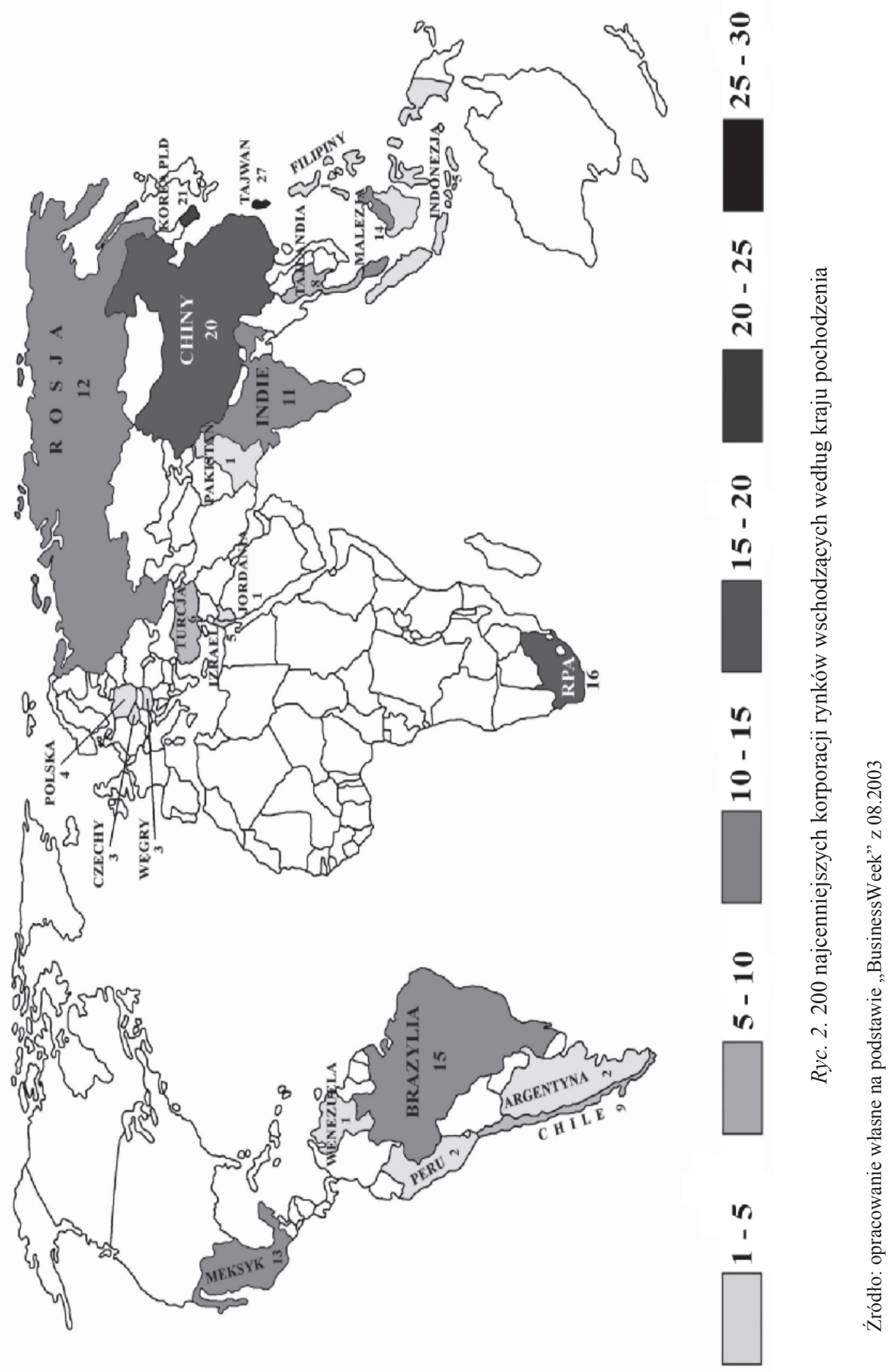


Tabela 3. Polskie korporacje na tle największych korporacji świata z listy Global 1000

\begin{tabular}{|c|c|c|c|c|}
\hline \multicolumn{2}{|c|}{ Pozycja } & \multirow{2}{*}{ Nazwa korporacji } & \multirow{2}{*}{ Kraj pochodzenia } & \multirow{2}{*}{ Wartość rynkowa w mld USD } \\
\hline 2004 & 2003 & & & \\
\hline 1. & 1. & General Electric & USA & 328,11 \\
\hline 985. & 877. & Bank Pekao & Polska & 5,42 \\
\hline 987. & 737. & Telekomunikacja Polska SA & Polska & 5,42 \\
\hline 1000. & - & CITIC Pacific & Chiny & 5,34 \\
\hline
\end{tabular}

Źródło: Opracowanie własne na podstawie „BusinessWeek” z 08.2003

\section{POLSKIE FIRMY RODZINNE NA TLE NAJWIĘKSZYCH FIRM RODZINNYCH ŚWIATA}

Szczególnym rodzajem firm są firmy rodzinne, z którymi właściciele są dodatkowo emocjonalnie związani. Pracownikami są często osoby wybierane przede wszystkim z rodzinnego grona i traktowane szczególnie, bo od początku obdarzane zaufaniem, co rodzi pozytywną atmosferę [Gocławska, Krysiak 2004]. Za tworzeniem firm rodzinnych przemawiają następujące argumenty:

- rodzina motywuje do starania się o jak najwyższą jakość wyrobów,

- praca w firmie rodzinnej daje poczucie niezależności,

- pracownicy są bardziej emocjonalnie związani z firmą rodzinną, co zwiększa ich motywację do działania,

- dobra atmosfera sprzyja zaangażowaniu, a szczególnie szybkości podejmowania decyzji.

Natomiast do powtarzanych mankamentów firm rodzinnych należy zaliczyć przenikanie się życia zawodowego i prywatnego, niejasny podział kompetencji czy trudności z obiektywną oceną efektów pracy, co nie sprzyja trafnym radykalnym decyzjom personalnym [Gocławska, Krysiak 2004].

Z historycznego punktu widzenia, zachodnie firmy rodzinne miały znacznie więcej czasu na rozwój w porównaniu z polskimi, które tak naprawdę mogły zacząć się rozwijać dopiero od początku lat 90 . XX wieku.

Tabela 4. Największe polskie firmy rodzinne na tle największych firm rodzinnych świata

\begin{tabular}{|r|l|l|l|r|}
\hline Lp. & \multicolumn{1}{|c|}{ Nazwa firmy } & \multicolumn{1}{|c|}{ Rodzaj działalności } & \multicolumn{1}{c|}{ Rodzina } & $\begin{array}{r}\text { Przychody } \\
\text { w mld USD }\end{array}$ \\
\hline 1. & $\begin{array}{l}\text { Wall-Mart Stores } \\
\text { Farmacol }\end{array}$ & $\begin{array}{l}\text { Handel } \\
\text { Dystrybucja } \\
\text { farmaceutyków }\end{array}$ & $\begin{array}{l}\text { Walton } \\
\text { Olszewski }\end{array}$ & $\begin{array}{r}\mathbf{2 , 7} \\
\end{array}$ \\
\hline 2. & Ford Motor & Motoryzacja & Ford & 163,4 \\
& Kulczyk Holding & Handel & Kulczyk & $\mathbf{2 , 4}$ \\
\hline 3. & Samsung & Elektroniczna & Lee & 98,7 \\
& Kulczyk Tradex & Handel & Kulczyk & $\mathbf{1 , 6}$ \\
\hline 4. & LG & Elektroniczna & Koo & 81,0 \\
& Gant SA & Holding wielobranżowy & Antkowiak & $\mathbf{1 , 4}$ \\
\hline
\end{tabular}




\begin{tabular}{|c|c|c|c|c|}
\hline 5. & \begin{tabular}{|l} 
Carrefour \\
Torfam
\end{tabular} & \begin{tabular}{|l} 
Handel \\
Dystrybucja farmaceutyków
\end{tabular} & \begin{tabular}{|l|} 
Defforey \\
Herba
\end{tabular} & $\begin{array}{r}72,0 \\
\mathbf{1 , 1} \\
\end{array}$ \\
\hline 6. & \begin{tabular}{|l|} 
Fiat Group \\
Farmutil \\
\end{tabular} & \begin{tabular}{|l|} 
Motoryzacyjna \\
Przetwórstwo i handel mięsem
\end{tabular} & $\begin{array}{l}\text { Angelli } \\
\text { Stokłosa }\end{array}$ & $\begin{array}{r}61,0 \\
\mathbf{0 , 7 8} \\
\end{array}$ \\
\hline 7. & $\begin{array}{l}\text { Ifi S.p. A. } \\
\text { AB SA }\end{array}$ & \begin{tabular}{|l|} 
Finansowa \\
Dystrybucja sprzętu kompu- \\
terowego
\end{tabular} & $\begin{array}{l}\text { Angelli } \\
\text { Przybyło }\end{array}$ & $\begin{array}{r}59,2 \\
\mathbf{0 , 6 5}\end{array}$ \\
\hline 8. & $\begin{array}{l}\text { PSA Peugeot } \\
\text { Grupa Wistil }\end{array}$ & $\begin{array}{l}\text { Motoryzacyjna } \\
\text { Dziewiarstwo }\end{array}$ & \begin{tabular}{|l} 
Peugeot \\
Kwiecień
\end{tabular} & $\begin{array}{r}57,0 \\
\mathbf{0 , 5 9} \\
\end{array}$ \\
\hline 9. & $\begin{array}{l}\text { Cargill Inc. } \\
\text { KEM }\end{array}$ & \begin{tabular}{|l} 
Spożywcza \\
Handel stalą
\end{tabular} & $\begin{array}{l}\text { Cargill, McMillan } \\
\text { Krawczyk }\end{array}$ & $\begin{array}{r}50,8 \\
\mathbf{0 , 5 4}\end{array}$ \\
\hline 10. & $\begin{array}{l}\text { BMW } \\
\text { Bać-Pol }\end{array}$ & $\begin{array}{l}\text { Motoryzacyjna } \\
\text { Handel }\end{array}$ & $\begin{array}{l}\text { Quandt } \\
\text { Bać }\end{array}$ & $\begin{array}{r}44,3 \\
\mathbf{0 , 4 9} \\
\end{array}$ \\
\hline
\end{tabular}

Źródło: opracowanie własne na podstawie: „BusinessWeek” z 14-27.10.2004

Analiza danych przedstawionych w tabeli 4, w której porównano pod względem przychodów czołówkę polskich i zachodnich firm rodzinnych świata, potwierdza istnienie bardzo dużego dystansu w przychodach między polskimi a zagranicznymi firmami rodzinnymi. Przychody największej polskiej firmy rodzinnej Farmacol stanowią zaledwie ok. 1,1\% przychodów największej na świecie firmy rodzinnej. Przychody pierwszej dziesiątki najbardziej dochodowych firm rodzinnych Polski kształtują się w przedziale między 1-2\% w porównaniu z dziesiątką najbardziej dochodowych firm rodzinnych świata.

\section{POLSKIE MARKI NA TLE MAREK ZACHODNICH}

Jedną z konsekwencji procesów globalizacji jest szeroko rozumiana unifikacja. W wyniku zunifikowanych procesów produkcji powstają podobne jakościowo produkty, których różnica w jakości nie przekłada się na różnicę w cenie. W związku z powyższym wymyślono markę, która ma wyróżniać dany produkt z klasy produktów podobnych. Poszczególne firmy starają się tworzyć otoczki kultowe wokół swoich produktów oraz nabywców i użytkowników. W efekcie powstaje grupa najwierniejszych użytkowników, która ma poczucie odrębności, wynikające z posługiwania się artykułami egalitarnymi. Poszczególne koncerny przeznaczają niejednokrotnie miliony dolarów na wykreowanie danej marki, gdyż markowe produkty sprzedają się znacznie lepiej od produktów nie markowych. Markę bardzo trudno wykreować, ale też bardzo łatwo stracić. Dlatego poszczególne koncerny starają się za wszelką cenę utrzymać wysokie notowania marki.

Na światowej arenie wyraźnie dominują marki amerykańskie. W pierwszej setce najwartościowszych marek świata znajduje się 58 marek amerykańskich, 8 niemieckich, 8 francuskich, 7 japońskich, 5 brytyjskich, 4 holenderskie, 3 włoskie, 3 szwajcarskie, 2 szwedzkie, 1 fińska oraz 1 południowokoreańska. Wartość czołowych marek świata liczona jest w mln USD. Za najwartościowszą markę świata uważa się Coca Colę, która wyceniona została na $67 \mathrm{mln}$ USD, drugie miejsce zajmuje Microsoft (61 mln USD), a trzecie IBM (53 mln USD). Kolejne miejsca zajmują GE (44 $\mathrm{mln}$ USD), Intel (33 $\mathrm{mln}$ USD), Disney (27 $\mathrm{mln}$ USD), McDonald (25 mln USD), Nokia (24 mln USD), Toyota (22 mln USD), oraz Marlboro (22 mln USD), które zamyka pierwszą dziesiątkę. 
Wartość polskich marek jest wielokrotnie niższa (tab. 5), co wynika z faktu stosunkowo krótkiej historii polskich firm oraz małego zasięgu oddziaływania. Polskie marki w zdecydowanej większości są rozpoznawalne na rynku polskim. Jedynie Polski Koncern Naftowy ORLEN próbuje zaistnieć na rynku międzynarodowym.

Pomimo bardzo dużej różnicy między polskimi a zagranicznymi markami, polskie na lokalnym rynku radzą sobie bardzo dobrze (tab. 5). Najwartościowsza polska marka ORLEN z powodzeniem konkuruje z British Petrolium, która zajmuję 72 pozycję na liście najwartościowszych marek świata. Odpowiednio ich udział procentowy na rynku polskim wynosi 40 i 4\%. Nakłady marketingowe ORLENU pozwoliły na zdystansowanie zagranicznego giganta. Podobnie sobie radzą na lokalnym rynku Amica i Wedel, których procentowy udział w rynku jest znacznie większy w porównaniu do zagranicznych konkurentów. Dopiero Hoop i Mlekowita uległy zachodnim markom. Hoop ma bardzo trudne zadanie na rynku, ponieważ rywalizuje z najwartościowszą marką na świecie, jaką jest Coca Cola, natomiast Mlekowita przegrywa rywalizację z francuską marką Danone, która jest klasyfikowana na 63 miejscu na świecie w $2004 \mathrm{r}$.

Tabela 5. Najwartościowsze polskie marki na tle najwartościowszych marek świata w danej branży w $2004 \mathrm{r}$.

\begin{tabular}{|l|l|c|c|c|}
\hline Lp. & \multicolumn{1}{|c|}{ Nazwa marki } & $\begin{array}{c}\text { Wartość marki } \\
\text { w mln USD }\end{array}$ & $\begin{array}{c}\text { Udział procentowy } \\
\text { w polskim rynku }\end{array}$ & $\begin{array}{c}\text { Znajomość marki } \\
(\%)\end{array}$ \\
\hline 1. & PKN Orlen & $\mathbf{4 4 0}$ & $\mathbf{4 0}$ & $\mathbf{7 2}$ \\
& British Petrolium & 3600 & 4 & 48 \\
\hline 2. & Amica S.A. & $\mathbf{9 8}$ & $\mathbf{3 4}$ & $\mathbf{6 9}$ \\
& Philips & 4300 & 14 & 80 \\
\hline 3. & Wedel & $\mathbf{6 8}$ & $\mathbf{2 4}$ & $\mathbf{8 6}$ \\
& Nestle & 4500 & 6,4 & - \\
\hline 4. & Hoop & $\mathbf{3 6}$ & $\mathbf{1 1}$ & 96 \\
& Coca Cola & 67000 & 25,5 & $\mathbf{5 5}$ \\
\hline 5. & Mlekowita & $\mathbf{6 4}$ & $\mathbf{5}$ & 82 \\
\hline
\end{tabular}

Źródło: M. Gocławska, I. Krysiak, 2004, Kiedy nazwisko staje się markq, „BusinessWeek”, z 14-27.10.2004

Przedstawiając polskie korporacje na tle korporacji zachodnich, porównując polskie firmy rodzinne z firmami zachodnimi oraz polskie marki z markami zachodnimi, zauważa się przede wszystkim dużą dysproporcję wartości na niekorzyść firm i marek polskich, co jest wynikiem niedokapitalizowania naszych rodzimych firm. Dostęp polskich firm do kapitału wydaję się być warunkiem koniecznym do dynamicznego rozwoju, gdyż małe polskie podmioty gospodarcze nie są w stanie same zakumulować środków na inwestycje oraz ponosić wysokich kosztów zaciągniętych pożyczek. W efekcie na rynku istnieje duża niestabilność poszczególnych firm, przejawiająca się nie tylko dużą rotacją w corocznych rankingach będącą wynikiem zmiennej niestabilnej dynamiki wzrostu, ale także wysokim odsetkiem bankructw. 
Silna konkurencja ze strony korporacji transnarodowych zmusza rodzime podmioty gospodarcze do pozyskania kapitału zagranicznego poprzez szukanie inwestorów zagranicznych (alianse, fuzje, przejęcia, porozumienia), wychodzenie z działalnością gospodarczą poza granice państwowe (eksport, filie) czy prowadzenie działalności handlowej z wykorzystaniem marki. Pośrednim etapem prowadzącym do celu jest tworzenie rodzimych grup kapitałowych, pozwalających na osiagnięcie pułapu umożliwiającego ekspansję na rynki zagraniczne.

Poszczególne przedsiębiorstwa poprzez koncentrację poziomą i pionową dążą do powiększenia udziału w rynku, a tym samym do zajęcia lepszej pozycji w stosunku do konkurencji. W dobie procesów globalizacji charakterystyczne jest nasilenie się procesów koncentracji, co wymuszone jest logiką rynku.

Reasumując, polskie firmy nie odgrywają istotnej roli na rynku międzynarodowym i choć w liczbach bezwzględnych rozwój polskich przedsiębiorstw należy uznać za oczywisty, to jednak ich tempo rozwoju jest niewystarczające. Jeżeli polskie firmy chcą dogonić zachodnie, muszą znacznie zwiększyć tempo rozwoju.

\section{Literatura}

200 najcenniejszych firm rynków wschodzacych, „BusinessWeek” z 08.2003

Global 1000, „BusinessWeek” z 08.2003

Gocławska M., Krysiak I., Kiedy nazwisko staje się marka, „BusinessWeek” z 14-27.10.2004

Czekański M., Dec Ł., Jakość musi kosztować, „Rzeczpospolita” z 12.10.2004

Cziomer E., Zyblikiewicz L. 2000, Zarys współczesnych stosunków międzynarodowych, Wydawnictwo Naukowe PWN, Warszawa-Kraków

Domański B. 1996, Wptyw inwestycji zagranicznych na gospodarkę województwa, [w:] Raport o stanie inwestycji zagranicznych $w$ województwie krakowskim, Urząd Miasta Krakowa, Kraków

Domański B. 2001, Kapitał zagraniczny w przemyśle Polski. Prawidłowości rozmieszczenia, uwarunkowania i skutki, Instytut Geografii I Gospodarki Przestrzennej UJ, Kraków

Domański B. 2002, Zagraniczne inwestycje przemysłowe a obszary metropolitalne, [w:] Problemy transformacji struktur przemysłowych, red. Z. Zioło, Prace Komisji Geografii Przemysłu PTG nr 4, Warszawa-Kraków-Rzeszów

Firmy Państwa, ,Wprost” z dn. 27.04.2003

Jarczewska- Romaniuk A. 2004, Przedsiębiorstwa międzynarodowe, Oficyna Wydawnicza BRANTA, Bydgoszcz-Warszawa

Karaszewski W. red., 2003, Bezpośrednie inwestycje zagraniczne w Polsce, Wydawnictwo Pacific, Toruń

Kisiel-Łowczyc A.B. 2000, Współczesna gospodarka światowa, Wydawnictwo Uniwersytetu Gdańskiego, Gdańsk

Kośmicki E. 2001, Obietnice globalnego kapitalizmu, „Dziś”, nr 1

Lista 2000, „Rzeczpospolita” z 12.09.2004

Romanowaska M., Trocki M., Wawrzyniak B. 2000, Grupy kapitałowe w Polsce, Wydawnictwa Difin, Warszawa

Skodlarski J., Matera R. 2004, Gospodarka światowa. Geneza i rozwój, PWN, Warszawa

Sala S. 2003, Wybrane cechy działalności korporacji transnarodowych i ich implikacje dla Polski, [w:] Przemyst w procesie globalizacji, red. Z. Zioło, Z. Makieła, Prace Komisji Geografii Przemysłu PTG nr 6, Warszawa-Kraków

Thurow L. 1996, The Future of Capitalism. How Today's Economic Forces Shape Tommorow's World, Nicholas Brealey Publishing, London 
Thurow L. Nowa rewolucja, nowe średniowiecze, „Gazeta Wyborcza” z 27-28.09.1997

Thurow L. 1999, Przyszłość kapitalizmu. Jak dzisiejsze sily ekonomiczne ksztaltuja świat jutra, Wrocław

UNCTAD, 2001, World Investment Report

Zorska A. 2000, Ku globalizacji. Przemiany w korporacjach transnarodowych $i$ w gospodarce światowej, PWN, Warszawa

Zorska A. red., 2002, Korporacje międzynarodowe w Polsce, Wydawnictwo Difin, Warszawa

\section{Polish corporations against foreign corporations in the age of globalization}

This article presents the role and the importance of Polish Transnational Corporations (TC) to global economy. Dynamic development of TC can be observed since the beginning of $70 \mathrm{~s}$ of the $20^{\text {th }}$ century. Nowadays TC have huge economic power which generates large profits. Many times incomes of TC are bigger than the value of GDP of less developed countries. Activity of TC is very controversial. On the one hand, present TC should be treated as an answer to qualitative changes which have taken place mainly in the sphere of telecommunication and means of transport, on the other hand, they are the motive power of these changes.

Polish corporations are very small in comparison with the foreign ones. We have noticed a great disproportion of worth in comparison with corporations which are on the list of the global 1000 or 2000 biggest-worth corporations on the rising market. If Polish corporations want to catch up with the foreign ones, they must considerably increase the speed of their development. 